\title{
ACÉL PRÓBATESTEK KORRÓZIÓS VIZSGÁLATA
}

\section{CORROSION INVESTIGATION OF STEEL SAMPLES}

\author{
Haraszti Ferenc \\ Óbudai Egyetem, Bánki Donát Gépész és Biztonságtechnikai Mérnöki Kar, Gépésze- \\ ti és Biztonságtudományi Intézet, Cím: 1081, Magyarország, Budapest Népszínház \\ utca 8 ;
}

\begin{abstract}
The corrosion process is a very difficult and compound. Measurability is also difficult and need experience. The purpose of this paper to shows the corrosion process without completeness of this topic. In my article I'm sowing some different corrosion process on the way of real corrosion tests.

Keywords: corrosion, steel, stainless steel.

\section{Összefoglalás}

A korróziós folyamatok összetett, sokrétü és bonyolult jelenségek. Mérhetőségük is nehéz, nagy felkészültséget, sok éves rutint igénylő feladat. A tanulmány célja - a teljesség igénye nélkül - bemutatni a legjellemzőbb korróziós folyamatokat és gyakorlati példán keresztül érthetőbbé tenni. Cikkemben konkrét mérési feladaton keresztül vizsgálok meg különféle acélokat korróziós szempontból.
\end{abstract}

Kulcsszavak: korrózió, acél, korrózióálló acél.

\section{Bevezetés}

A fémek korróziója igen veszélyes károsodási forma lehet. Különböző megjelenési formáival találkozhatunk az ipari gyakorlatban. A korrózió bizonyos típusai jól megfigyelhetőek, károsító hatásuk jellemezhető, leírható, mérhető. Vannak azonban olyan korróziós folyamatok, melyek hatására létrejövő anyagveszteség nem szembetünő, ezzel szemben katasztrófák okozói lehetnek. Ilyen korrózió a kristályszerkezeti és a szelektív korrózió. Előbbi kialakulhat a fém kristályhatárai mentén és magában a kristályban is. A legveszélyesebb károsodások közé tartoznak, mivel szabad szemmel többnyire nem érzékelhetőek, továbbá meggyengítik a fém belső szerkezetét, ami szilárdságcsökkenést okoz.
Szelektív korrózió esetén pedig a fémkristályban található ötvöző egyes fázisainak kiválásáról beszélünk.

Igen fontos, hogy a korróziót megakadályozzuk, illetve felismerjük. Ehhez azonban ismernünk kell az alkalmazott anyagok öszszetételét, szerkezetét és viselkedését különböző hatásokra. A dolgozatban röviden ismertetem korrózió megjelenési formáit valamint a szemcsehatár menti korróziót. Bemutatom a vizsgált anyagminőséget, mely alapvetően korrózióálló acél, de korrózióállósága változhat a képlékeny alakítás valamint hőkezelés hatására.

\subsection{Korróziós elváltozások megjele- nési formái [4]}

A következő főbb csoportokat különböztetjük meg: 
- egyenletes korrózió,

- lyukkorrózió,

- kristályszerkezeti korrózió,

- Korróziós kifáradás,

- különleges korrózió.

1.2. Az egyenletes korrózió egy igen jól nyomon követhetö, a felületen egyenletesen megjelenő anyagveszteséget okozó károsodási forma. Mivel szemmel látható, így a károsodás mértéke követhetö, ezért nem tekinthető veszélyes korróziós típusnak. Mértéke súly- vagy térfogatváltozás mérésével jól meghatározható.

1.3. Lyukkorrózió előfordulása igen sokrétü. A szakirodalom ide sorolja a szivacsos korróziót, a pontkorróziót a különféle bemaródásokat. Jellemzőjük, hogy a fém oldódása nem egyenletes. Mindig valamilyen definiálható hatás miatt alakul ki. Meghatározása nehézkes, egyidejűleg több mérési módszer alkalmazása szükséges.

1.4. Kristályszerkezeti korrózió igen veszélyes, alattomos korrózió típus, mely katasztrófák okozója lehet. Az ausztenites korrózióálló acélok bizonyos típusainál jellemzően megfigyelhetö [1]. Oka a szemcsehatárok mentén kiváló krómkarbid (Cr23C6), ennek környezetében a króm mennyisége lecsökken elveszítve ezzel a korrózióállóságot. Ez az anyagon belül a szemcsehatárokra koncentrálódik, melynek oka, hogy a korróziós jelenség is a szemcsehatáron mutatkozik meg. A kiválás mértéke, nagyban függ a fém szén tartalmától és rendkívüli mértékben rontja az ausztenites acél szilárdsági mutatóit az alacsony hömérsékleten történt hökezelés miatt (1. ábra). Ez a hőmérsékletköz azonban szerencsére igen kicsi. Rövid ideig tartó hőkezelés jelentősen lecsökkenti azt a hőtartományt, ahol a korrózióérzékenység kialakulhat. Abban az esetben, ha az alkatrész nem csak korrozív közegnek, de egyben húzó igénybevételnek is kitett a korrózió fokozottabban lép fel. Mérése eltér a fent említettektől. Többnyire a megváltozott szilárdsági és elektromos tulajdonságok meghatározásán alapul.

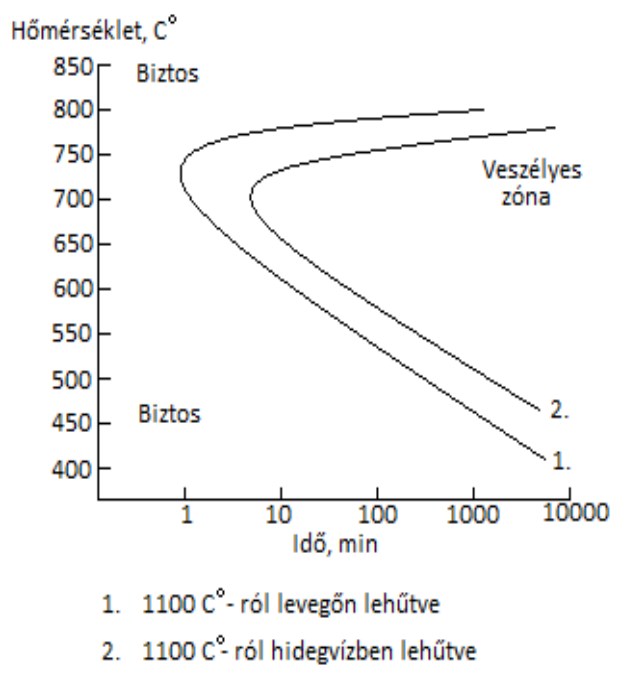

1.ábra. Cr-Ni acélok korrózióerzékenységi tartományai [4]

\section{A vizsgált acélminőség}

Vizsgálataimat X15CrNiSi25-21 (1.4841) acélminőségủ korrózióálló acél próbatesteken végeztem.

1. táblázat. $A$ vizsgált acél fö ötvözöi

\begin{tabular}{|c|c|c|c|c|c|}
\hline $\mathrm{C} \%$ & $\mathrm{Cr} \%$ & $\mathrm{Ni} \%$ & $\mathrm{Mn} \%$ & $\mathrm{~N} \%$ & $\mathrm{Si}$ \\
\hline $\max$. & $24,00-$ & $19,00-$ & $\max$. & $\max$. & $1,50-$ \\
0,20 & 26,00 & 22,00 & 2,00 & 0,11 & 2,50 \\
\hline
\end{tabular}

Szakirodalmi hivatkozás szerint[2] az AISI 316 jelölésü ausztenites acél korróziós vizsgálata alapján bizonyítást nyert, hogy a szekunder fázisok kiválására az alakváltozás mértéke jelentősen hat.

A megvizsgált acél is ausztenites, bár kémiai összetételében eltér az irodalomban találttól, kísérleteim során az alakítás korrózióállóságra gyakorolt hatását kívántam elemezni.

Az általam korróziós kísérletnek alávetett darabok a következőek voltak. Az 
1. táblázat szerinti összetételü acélminőség, alakítatlan állapotban, valamint 50\%-os alakítás után (2. táblázat) illetve $50 \%$ alakítás és $500^{\circ} \mathrm{C}$-os hőkezelés utáni állapotban (3. táblázat).

\section{Korróziós vizsgálatok}

A korróziós igénybevételnek kitett próbatesteket az alábbi módszerrel vizsgáltuk: a vizsgálandó acélokat zsírtalanítás (absz. alkohol) után pácolásnak (15 V/V[\%] Hcl oldat) tettük ki. Az előkészítés minden zsírt és egyéb szennyeződést leoldott. Gondos szárítás után (főn) mérlegelés következett analitikai mérleggel (d=0,1mg osztályú). A szárítószekrény hőmérséklete $55^{\circ} \mathrm{C}$-ra lett beállítva. Ebbe került a hőálló főzőpohár túltelített sóoldattal (36 m/m\%), melyben a próbadarabok vizsgálata egy hetet vett igénybe. Ez a közeg rendkívül korrozív hatásnak teszi ki a vizsgálandó acél próbatesteket. Az elpárolgott oldatot naponta pótoltuk. A kísérlet lejárta után öblítés, szárítás majd a mérlegelés következett. Az eredmények az alábbi táblázatokban követhetők:

2.táblázat. A vizsgált acél súlyveszteségei

\begin{tabular}{|c|c|c|c|c|c|c|}
\hline & \multicolumn{3}{|c|}{ Ausztenites rugó } & \multicolumn{3}{|c|}{$\begin{array}{c}\text { Hagyományos } \\
\text { rugóacél }\end{array}$} \\
\hline & $\begin{array}{c}1 . \\
\text { rugó }\end{array}$ & $\begin{array}{c}2 . \\
\text { rugó* }\end{array}$ & $\begin{array}{l}3 . \\
\text { rugó }\end{array}$ & \begin{tabular}{c|}
1. \\
rugó
\end{tabular} & $\begin{array}{c}2 . \\
\text { rugó* }\end{array}$ & $\begin{array}{c}3 . \\
\text { rugó }\end{array}$ \\
\hline $\begin{array}{l}\text { Vizs- } \\
\text { gálat } \\
\text { előtti } \\
\text { súly } \\
\text { (g) }\end{array}$ & 2,4193 & 2,3634 & 2,2465 & 5,5197 & 5,5134 & 9,3852 \\
\hline $\begin{array}{l}\text { Vizs- } \\
\text { gálat } \\
\text { utáni } \\
\text { súly } \\
\text { (g) }\end{array}$ & 2,4193 & 2,3634 & 2,2465 & 5,5123 & 5,5104 & 9,3777 \\
\hline $\begin{array}{l}\text { Küi- } \\
\text { lönbsé } \\
\text { g (g) }\end{array}$ & 0 & 0 & 0 & 0,0074 & 0,003 & 0,0075 \\
\hline $\begin{array}{l}\text { Fogyás } \\
(\%)\end{array}$ & 0 & 0 & 0 & 0,134 & 0,054 & 0,080 \\
\hline 55 & tú & to & $\mathrm{aC}$ & ath & & \\
\hline
\end{tabular}

3.táblázat. Hökezelt acél súlyveszteségei

\begin{tabular}{|c|c|c|c|c|}
\hline & $\begin{array}{l}\text { Huzal- } \\
\text { dara- } \\
\text { bok }\end{array}$ & $\begin{array}{l}\text { Mérés } \\
\text { elötti } \\
\text { tömeg } \\
\text { (g) }\end{array}$ & $\begin{array}{l}\text { Mérés } \\
\text { utáni } \\
\text { tömeg } \\
\text { (g) }\end{array}$ & $\begin{array}{l}\text { Fogyás } \\
(\%)\end{array}$ \\
\hline \multirow{3}{*}{$\begin{array}{l}\text { Szobahőmé } \\
\text { r-sékleten }\end{array}$} & 1 & 0,1149 & 0,1147 & 0,1741 \\
\hline & 2 & 0,2106 & 0,2104 & 0,0950 \\
\hline & 3 & 0,2243 & 0,2243 & 0,0000 \\
\hline \multirow{3}{*}{$55^{\circ} \mathrm{C}$-on } & 4 & 0,2028 & 0,2026 & 0,0986 \\
\hline & 5 & 0,1569 & 0,1567 & 0,1275 \\
\hline & 6 & 0,1497 & 0,1496 & 0,0668 \\
\hline
\end{tabular}

\section{Eredmények és következtetések}

Az eredményekből jól látható, hogy azonos kísérleti idők mellett az alakítás nélküli és az alakított ausztenites acél alkatrészek esetén anyagveszteség nem tapasztalható, míg a kontroll csoportként használt rugóacélok esetében mérhető. Azt is meg kell állapítanom, hogy az alakított és hőkezelt darabok esetében az alkalmazott analitikai mérleggel anyagveszteséget mutattam ki. Feltehető, hogy az alakítás és a hőkezelés együttes hatása olyan nem kívánt anyagszerkezeti változásokat okozott, mely korrózióállósági szempontból káros hatású.

\section{Összefoglalás}

A cikkben kísérletet próbáltam tenni a korrózió okozta károk főbb megjelenési formájának bemutatására. A hely szükössége miatt ez csak a legjellemzőbb elektrokémiai korróziós elváltozásokra terjedt ki. Bemutattam a felületi- a lyuk- és a kristályszerkezeti korrózió legfontosabb paramétereit kialakulásának okait és mértékének meghatározásait. Gyakorlati méréssel igazoltam az ausztenites valamint a közönséges szénacél alakításának, hőkezelésének összefüggéseit a korróziós érzékenységgel szemben. Az elözetes várakozásnak megfelelően az ausztenites acél korrózióra való hajlama nem függ az alakítás mértékétől. 
Az ötvözésnél használt króm és nikkel megvédi a fémet egy bizonyos határig ettől az igénybevételtől. Ezzel ellentétben a hagyományos ötvözetlen szénacél érzékeny az alakítás folyamatára korróziós szempontból. Az elvégzett mérés kimutatta, hogy az alakítás hőkezeléssel párosítva minden esetben anyagveszteséggel járt. Az alkalmazott egyszerü mérési metódust a jövőben hosszabb és bonyolultabb eljárásokkal kiegészítve valószínüsíthető, hogy választ kaphatunk milyen nem kívánt anyagszerkezeti változást okozott az említett együttes igénybevétel a fém belsejében.

\section{Köszönetnyilvánítás}

A korróziós kísérletekben való közremüködésért szeretnék köszönetet mondani
Dr. Kovács Tünde egyetemi docensnek és Szigeti Ádám BSC egyetemi hallgatónak.

\section{Szakirodalmi hivatkozások}

[1] Kocsisová E.; Dománková M.: Másodlagos fázisok kiválásának vizsgálata AISI 316 ausztenites korrózióálló acélban EME kiadó, Kolozsvár, 2013, 189-192.

[2] Kovács-Coskun T.; Völgyi B.; Sikari-Nágl I.: Kontaktkorróziós jelenség tanulmányozása acél aluminium párositásánál EME kiadó, Kolozsvár, 2013, 201-204.

[3] Reti T, Kovacs T: A phenomenological method for the prediction of damage accumulation processes under varying external conditions In: Materials Science Forum, Vol. 414-415: 2003, 317-322.

[4] Kovács Klára: Korróziós alapfogalmak Müszaki Könyvkiadó, Budapest 1965. 